MONIKA KOZŁOWSKA

Instytut Historii i Nauk Politycznych Uniwersytetu w Białymstoku

\title{
RYNEK KREDYTOWY W OSIEMNASTOWIECZNYM BIAŁYMSTOKU W ŚWIETLE ANALIZY KSIĄG MIEJSKICH
}

Zarys treści: Artykuł przedstawia wyniki analiz funkcjonowania rynku kredytowego w Białymstoku w drugiej połowie XVIII w. Materiałem źródłowym, na którym oparto badania, są najstarsze zachowane księgi miejskie Białegostoku. Podstawę tę uzupełniaja dokumenty z przechowywanych w AGAD zespołów Archiwum Roskiego oraz Archiwum Branickich z Białegostoku. Badaniu poddano takie elementy charakteryzujące rynek kredytowy jak: wartość zapisów, struktura obrotów, czas trwania umów oraz sposoby zabezpieczenia kontraktów.

The content outline: The article presents the results of analyses of the functioning of the credit market in Białystok in the second half of the eighteenth century. The studies have been based on the oldest municipal registers preserved in Białystok, which were supplemented by documents kept in the Roskie Archives and the Branicki Archives in Białystok. The analyses included such elements of the credit market as: the values of entries, turnover structure, duration of agreements, and contract guarantees.

Słowa kluczowe: miasto prywatne, Białystok, rynek kredytowy, historia gospodarcza

Keywords: private town, Białystok, credit market, economic history

Problematyka dziejów miast od dawna była przedmiotem zainteresowania wielu historyków ${ }^{1}$. Podnoszono przede wszystkim kwestie dotyczące początków funkcjonowania ośrodków miejskich, ich liczebności, układu urbanistycznego, kultury, roli politycznej oraz społecznej.

${ }^{1}$ Zob. A. Wyrobisz, Rola miast prywatnych $w$ Polsce $w$ XVI $i$ XVII, PH, t. 65, 1974, z. 1, s. 19-46; B. Baranowski, Życie codzienne matego miasteczka $w$ XVII $i$ XVIII w., Warszawa 1975; M. Bogucka, H. Samsonowicz, Dzieje miast i mieszczaństwa $w$ Polsce przedrozbiorowej, Wrocław 1986. 
Jednakże zagadnienia stricte gospodarcze znacznie rzadziej znajdowały się w centrum uwagi, często przedstawiane były w sposób pobieżny, $\mathrm{z}$ pominięciem podstawowej $\mathrm{w}$ tego typu studiach analizy kwantytatywnej zjawisk. Również w literaturze przedmiotu dotyczącej osiemnastowiecznego Białegostoku dominuja kwestie funkcjonowania dworu hetmana Jana Klemensa Branickiego i jego żony, a potem wdowy, królewskiej siostry - Izabeli z Poniatowskich oraz mniej lub bardziej oficjalne wizyty dostojnych gości. Przez wiele lat zagadnienia dotyczące funkcjonowania organizmu miejskiego oraz codziennej egzystencji mieszkańców pozostawały w cieniu badań nad podlaskim Wersalem.

Celem niniejszego artykułu jest ukazanie i omówienie zjawiska kredytu w niewielkim miasteczku prywatnym na przykładzie Białegostoku w drugiej połowie XVIII stulecia. Określenie wysokości i struktury obrotów, długości trwania umów oraz sposobu ich zabezpieczania pozwoli zarysować rytm życia gospodarczego analizowanego ośrodka miejskiego i pomoże określić stopień jego rozwoju ekonomicznego. Analizę oparto na najstarszych zachowanych księgach miejskich Białegostoku². Materiały te uzupełniaja dokumenty z Archiwum Roskiego ${ }^{3}$ oraz Archiwum Branickich z Białegostoku4. Zachowały się tylko trzy woluminy ksiąg miejskich, obejmujacce lata 1740-1795 (pierwszy zawiera wpisy z lat 1740-1786, drugi - 1768-1795, trzeci zaś 1772-1787), przechowywane w Archiwum Głównym Akt Dawnych w Warszawie ${ }^{5}$. Księgi te powstały w wyniku działalności dwóch sądów miejskich - burmistrzowskiego i landwójtowskiego. Wpisy tam zawarte cechuje duża różnorodność, jednakże nie odróżniają się one niczym specjalnym od zapisek dokonywanych w aktach innych ówczesnych miast Rzeczypospolitej. Treść białostockich ksiag miejskich możemy podzielić na sprawy karne - dotyczące pobić, zniesławień, kradzieży, zabójstw - oraz cywilne. Te ostatnie dodatkowo dzielą się na sprawy niesporne i sporne. Pierwsze z nich były wynikiem pełnienia przez magistrat funkcji urzędu notarialnego. Sa to przede wszystkim wszelkiego rodzaju kontrakty (kupna-sprzedaży nieruchomości, operacje kredytowe, podziały majątkowe), kwitancje, testamenty, inwentarze oraz plenipotencje. Z kolei sprawy sporne pojawiały

2 AGAD, Księgi miejskie białostockie, sygn. 1-3.

${ }^{3}$ AGAD, Archiwum Roskie, Akta osobisto-rodzinne i majątkowo-prawne, sygn. $628,633,634,636$.

${ }^{4}$ AGAD, Archiwum Branickich z Białegostoku, sygn. 8, 48.

${ }_{5}$ Najstarsza znana nam ewidencja podaje, że ksiąg miejskich białostockich było 14 . Późniejszy inwentarz archiwisty wileńskiego Sprogisa, sporządzony w 1906 r., mówi o 13 zachowanych woluminach; zob. A. Sztachelska, Trzy księi miejskie białostockie, „Archeion” 50, 1968, s. 121-122; taż, Źródła archiwalne do dziejów miasta Białegostoku w XVII i XVIII w. (do 1795 r.), „Rocznik Białostocki” 11, 1972, s. 307. 
się na skutek konfliktu między stronami w wyżej wymienionych kwestiach. Na potrzeby niniejszego artykułu zanalizowano zapiski zawierające informacje dotyczace rynku kredytowego.

Dzieje Białegostoku były przedmiotem wielu badań już od czasów dwudziestolecia międzywojennego. Wówczas to Henryk Mościcki wydał pierwsza publikację dotycząca tego ośrodka ${ }^{6}$. W okresie tym swoją działalność rozpoczał także Jan Glinka, który pozostawił po sobie ogromna dokumentację (odpisy oraz streszczenia dokumentów archiwalnych, notatki z literatury, zapiski z oględzin terenu, fotografie obiektów architektonicznych oraz własne opracowania) dotyczaca historii Białegostoku i północnego Podlasia ${ }^{7}$. Przez kolejne dziesięciolecia zagadnienia dotyczące funkcjonowania miasta rzadziej znajdowały się w centrum uwagi. Dopiero w latach 60. XX w. ponownie zainteresowano się tym ośrodkiem miejskim, wówczas powstały liczne prace poruszające problematykę społeczno-gospodarczą ${ }^{8}$. W bibliografii historii miasta ważną pozycję zajmują również opracowania Aliny Sztachelskiej-Kokoczki, której artykuły na temat zmian społecznych, przestrzennych oraz ustrojowych osiemnastowiecznego Białegostoku ukazywały się na łamach „Białostocczyzny"9. Należy także zaznaczyć, że w ostatnich latach opublikowano również wydawnictwa źródłowe dotyczące pałacu Branickich w Białymstoku $^{10}$ oraz spisy mieszkańców miasta ${ }^{11}$.

${ }^{6}$ H. Mościcki, Białystok - zarys historyczny, Białystok 1933.

7 Zawartość i znaczenie Tek Glinki szczegółowo omówiła T. Zielińska, Jan Glinka i jego spuścizna archiwalna, „Archeion” 53, 1970, s. 121-134.

${ }^{8}$ M.J. Lech, Białystok - miasto i jego mieszkańcy $w$ XVIII w., „Rocznik Białostocki” 6, 1965, s. 441-454; tenże, Dzieje i obraz Białegostoku w XVIII w., w: Studia i materiały do dziejów miasta Białegostoku, t. 1, red. J. Antoniewicz, J. Joka, Białystok 1968, s. 129-150; A. Oleksicki, Rozwój przestrzenny i struktura ludności Białegostoku w XVIII wieku, w: Studia nad społeczeństwem i gospodarka Podlasia w XVI-XVIII wieku, red. A. Wyrobisz, Warszawa 1981, s. 31-90; tenże, Socjotopografia Białegostoku w XVIII w. $w$ świetle inwentarza miasta z 1771/72 i planu Beckera z 1799 r., w: Studia i materiały do dziejów miasta Białegostoku, t. 4, red. H. Majecki, Białystok 1985, s. 41-56.

9 Artykuły te w 2009 r. autorka zebrała w jednej pozycji książkowej; A. Sztachelska-Kokoczka, Biatystok za pałacowa brama, Białystok 2009. Treść tam zawarta została następnie powtórzona w pracy zbiorowej dotyczącej historii Białegostoku od czasów najdawniejszych do XX w.; taż, Białystok w czasach Branickich (lata 1708-95), w: Historia Białegostoku, red. A. Dobroński, Białystok 2012, s. 97-197.

${ }^{10}$ Pałac Branickich w Biatymstoku, t. 1: Inwentarze $z$ XVII i XVIII stulecia, cz. 1-2, oprac. K. Łopatecki, W. Walczak, Białystok 2012; Pałac Branickich w Białymstoku, t. 2: Lata 1802-1809, oprac. K. Łopatecki, W. Walczak, Białystok 2015; K. Łopatecki, W. Walczak, The History of Branicki Palace until 1809. The Influence of „Versailles of Podlasie" on the Development of Biatystok, Białystok 2015.

11 Spisy mieszkańców Białegostoku z lat 1799-1853, oprac. W. Wróbel, Białystok 2016. 
W polskiej historiografii poruszano już również zagadnienie kredytu w Rzeczypospolitej przedrozbiorowej. Prace tego dotyczące w znacznym stopniu odnoszą się jednak do miast dużych (z wyjątkami, głównie w późnym średniowieczu ${ }^{12}$ ), a wczesnonowożytny rynek kredytowy regionów mniej rozwiniętych lub obszarów wiejskich pozostaje na marginesie zainteresowania badaczy ${ }^{13}$. Zagadnienia aktywności gospodarczej mieszkańców setek miast prywatnych, tak istotne w poznaniu ich roli i znaczenia w gospodarce, układach społecznych i kulturze, zarówno w kraju, jak i historii lokalnej, nadal pozostają dziedziną słabo opracowana.

$$
* * *
$$

Kredyt odgrywał ważną rolę w warunkach miejskich, gdyż tam najlepiej rozwinęła się gospodarka towarowo-pieniężna. Stosowano go zarówno w inwestycjach i obrotach towarowych, jak również w celach konsumpcyjnych, które stanowiły przeważający powód zaciagania pożyczek. Z kolei brak instytucji bankowych ${ }^{14}$, gdzie mieszczanie, szczególnie

${ }^{12}$ C. Kardasz, Rynek kredytu pieniężnego $w$ miastach południowego pobrzeża Battyku w późnym średniowieczu (Greifswald, Gdańsk, Elblag, Toruń, Rewel), Toruń 2013; M. Urbański, Niektóre problemy ruchu kredytowego w ziemi sanockiej $w X V w$., PH, t. 70, 1979, z. 4, s. 627-651; H. Samsonowicz, Studia nad renta miejska w Prusach w XV wieku, „Zapiski Historyczne” 25, 1960, z. 2, s. 35-57; U. Łydkowska-Sowina, Ruch kredytowy w późnośredniowiecznym Sieradzu - pożyczki pieniężne, w: Szkice z dziejów materialnego bytowania spoteczeństwa polskiego, red. M. Dembińska, Wrocław 1989, s. 119-135.

${ }_{13}$ A. Dunin-Wasowicz, Kapitat mieszczański Nowego Sacza na przełomie XVI/ XVII wieku. Wptyw na ekonomike miasta i zaplecza, Warszawa 1967; M. Bogucka, Obrót wekslowo-handlowy w Gdańsku w pierwszej połowie XVII wieku, RDSG, t. 33, 1972, s. 1-31; A. Mączak, Kredyt w gospodarce chłopskiej na Żuławach Malborskich poczatku XVII w., PH, t. 51, 1960, z. 2, s. 285-313; P. Szafran, Kredyt na Żuławach Gdańskich w XVII-XVIII wieku, „Rocznik Gdański” 45, 1985, z. 1, s. 139-148; J. Morgensztern, Operacje kredytowe Żydów w Zamościu w XVII w. (wierzytelności i zadtużenia), „Biuletyn Żydowskiego Instytutu Historycznego” 64, 1967, s. 3-32; R. Rybarski, Kredyt i lichwa w ekonomii samborskiej w XVIII wieku, Lwów 1936.

${ }^{14} \mathrm{Za}$ instytucję bankową należy uznać przedsiębiorstwo, które prowadzi trzy rodzaje operacji bankowych: bierną - polegającą na gromadzeniu środków pieniężnych przez zaciaganie zobowiązań, czynną - bazująca na udzielaniu kredytu czy finansowaniu inwestycji, oraz usługowa - przeprowadzana na rachunek i zlecenie klienta w zamian za prowizję; zob. H. Samsonowicz, Poczatki banków prywatnych w Polsce, „Śląski Kwartalnik Historyczny Sobótka” 36, 1981, nr 1, s. 128. Już w XVIII stuleciu bankierstwo powoli zaczęło odłączać się od kupiectwa, w epoce stanisławowskiej zaś nastapił znaczny rozwój polskiej bankowości. W 1790 r. na Sejmie Czteroletnim uchwalono nobilitację pierwszych bankierów Rzeczypospolitej. Jednakże w lutym 1793 r. doszło do zapaści systemu bankowego, w wyniku którego upadły największe polskie domy bankowe - Teppera, Szulca, Kabryta, Potockiego, Łyszkiewicza i Heyzlera. 
ci zamożniejsi, mogliby wziąć kredyt bądź ulokować swój majątek, wpłynął na znaczny rozwój wzajemnych pożyczek na procent. Należy zwrócić uwagę na dużą rolę, jaką odegrała ludność żydowska w rozwoju operacji kredytowo-pieniężnych na terenie badanego ośrodka ${ }^{15}$. Choć działalność finansowa kahału miała także ujemna stronę - nadmierne zadłużenie gminy żydowskiej w końcu XVIII w. powodowało jej niewypłacalność i konieczność ingerencji władzy dominalnej. Według specyfikacji długów przedstawionych w 1795 r. kahał był zadłużony na kwotę 11989 złp $3 \mathrm{gr}^{16}$. Z polecenia Izabeli Branickiej, dożywotniej posesorski miasta, część wierzytelności (1000 złp) pokrył skarb, a sumę w wysokości 1800 złp spłaciło miasto (gmina żydowska miała zwrócić niniejszą kwotę miastu z kwaterowych pieniędzy ${ }^{17}$. Z woli Izabeli Branickiej kahał pożyczył także 1226 złp od wdowy Marianny z Bronkowskich Puchalskiej - suma ta została przeznaczona na spłatę zaległych długów gminy ${ }^{18}$.

Na rozwój obrotów kredytowych mogły również wpływać instytucje kościelne, które zwykle dysponowały sporym zasobem gotówki (m.in. bractwa ${ }^{19}$ bądź dobrze uposażeni księża, pożyczający pieniądze na tzw. wyderkafy ${ }^{20}$ ). W analizowanym materiale źródłowym znaleziono szczątkowe informacje (jedynie 2 zapiski) odnoszące się do duchownych udzielajacych kredytu. Pierwszy wpis dotyczył długu Wolfa Gołdy, bogatego kupca handlu dalekosiężnego, który zapożyczył się u ks. Jeryka na sumę $222 z^{z ł p}{ }^{21}$, druga wierzytelność zaś - w wysokości 1400 złp zaciagnął białostocki kahał u ks. Łapinkiewicza, od tej pożyczki gmina żydowska płaciła $8 \%$ odsetek rocznie ${ }^{22}$. Także magistrat $\mathrm{w}$ pewien

W celu likwidacji niewypłacalnych firm na sejmie grodzieńskim powołano Komisję Bankowa. Kryzys przetrwały tylko nieliczne, małe banki; zob. W. Kornatowski, Kryzys bankowy w Polsce w 1793 roku: upadtość Teppera, Szulca, Kabryta, Prota Potockiego, Eyszkiewicza i Heyzlera, Warszawa 1937.

${ }_{15}$ Zob. A. Leszczyński, Żydzi Ziemi Bielskiej od połowy XVII w. do 1795 r. (studium osadnicze, prawne i ekonomiczne), Wrocław 1980, s. 188-202.

16 AGAD, Archiwum Roskie, Akta osobisto-rodzinne i majątkowo-prawne, sygn. 633 , s. 68 .

17 Tamże, s. 71.

18 Tamże, s. 73.

19 Zob. K. Pogorzelski, Podstawy materialne działalności konfraterni religijnych $w$ Wegrowie w XVII-XVIII stuleciu, w: Małe miasta. Gospodarka, red. M. Zemło, Lublin-Supraśl 2007, s. 293.

${ }^{20}$ Zob. P. Miodunka, Wojnicz $w$ drugiej połowie XVII wieku $i$ w wieku XVIII, w: W. Krawczuk, P. Miodunka, K. Nabiałek, Dzieje Wojnicza od XVI do XVIII wieku, Wojnicz 2009, s. 287-433, s. 411.

${ }^{21}$ AGAD, Księgi miejskie białostockie, sygn. 3, s. 77.

22 AGAD, Archiwum Roskie, Akta osobisto-rodzinne i majątkowo-prawne, sygn. 633 , s. 68-69. 
sposób wpływał na rynek kredytowy. Przed sądem miejskim upominano się o zwrot niespłacanych $\mathrm{w}$ terminie długów oraz zgłaszano do otaksowania zastawione przedmioty. Ponadto samorząd zajmował się licytowaniem majątków osób niemogących wywiązać się z zaciagniętych wierzytelności (choć czuwał nad tym gubernator oraz sami Braniccy ${ }^{23}$ ).

Ogromną rolę w białostockim rynku kredytowym odgrywali właściciele Białegostoku, co można było już zauważyć w przedstawionych wyżej przykładach. Duży wpływ wywierała zwłaszcza Izabela z Poniatowskich Branicka (w niniejszym artykule pragnę jedynie zasygnalizować to zagadnienie, które niewątpliwie stanowi temat na oddzielne opracowanie). Swoje pieniądze lokowali u niej mieszkańcy miasta, przede wszystkim zaś najwyżej postawieni w strukturze dworzanie. Na początku XIX w. u hetmanowej wysokie sumy zdeponowali m.in. adwokat Franciszek Ksawery Wilczewski (46 500 złp), sekretarz Jakub Popławski (21 600 złp), panny dworskie Józefa Duchaine (22 400 złp) i Magdalena Pichler (10 800 złp), kuchmistrz Józef Maliszewski (5000 złp), a także przyjaciółka Branickiej - Aniela z Kownackich Wolska (15 000 złp) ${ }^{24}$. Z kolei po śmierci Izabeli kilku osobom wypłacono prowizję od lokowanych pieniędzy. Odsetki otrzymali: bazylianie suprascy (2909 złp $17 \mathrm{gr}$ ), pani Rostkowska (2683 złp 10 gr; od długu w wysokości 70000 złp), sekretarz Jakub Popławski (1080 złp), Jan Borkowski (78 złp; od długu w wysokości $1300 \mathrm{złp)} \mathrm{oraz} \mathrm{żona} \mathrm{landrata} \mathrm{białostockiego} \mathrm{Michała} \mathrm{Czyża}$ $(810 \mathrm{złp})^{25}$. Zapewne analogicznych transakcji kredytowych było znacznie więcej, jednakże księgi sądowe nie uwzględniaja podobnych operacji. U hetmanowej swoje fundusze składali przede wszystkim najzamożniejsi mieszkańcy Białegostoku oraz innych miast i dóbr będących w posiadaniu Branickiej, a także osoby znajdujące się na szczycie hierarchii dworskiej.

Braniccy, jako właściciele miasta, dysponowali narzędziami kontrolującymi białostocki rynek kredytowy. Nad wszelkimi operacjami tego typu czuwał urzędnik dworski - gubernator Antoni Patyński²6. Urząd

${ }^{23} \mathrm{O}$ nadzorze Branickich nad obrotami kredytowymi w mieście świadczą m.in. odpowiedzi Izabeli Branickiej na kierowane do niej supliki w sprawie długów małżeństwa Boćkowskich oraz wydany w tej kwestii dekret sądu komisarskiego. Dokumenty te kierują sprawę do sądu miejskiego oraz polecaja, aby ten otaksował zastawione ruchomości oraz zlicytował majątek (dom i kram) dłużników; tamże, s. 30-39.

${ }^{24}$ K. Łopatecki, M. Kupczewska, Dyspozycje majatkowe Izabeli z Poniatowskich Branickiej na wypadek śmierci, KHKM, t. 64, 2016, nr 4, s. 485-493, s. 490.

${ }^{25}$ Ciż, Testament Izabeli z Poniatowskich Branickiej (3 XI 1805), KHKM, t. 64, 2016, nr 1, s. 109, przyp. 42.

${ }^{26}$ K. Łopatecki, Ustrój XVIII-wiecznego miasta Białystok, „Miscellanea Historico-Iuridica” 14, 2015, z. 1, s. 372-374; A. Sztachelska-Kokoczka, Białystok za pałacowa brama..., s. 21, 112 . 
gubernatora powołała w 1772 r. Izabela Branicka, przez co zmarginalizowała rolę zarówno burmistrza - bezpośrednio wkraczajac w jego kompetencje, jak również landwójta. Pokazuje to, jak duże możliwość ingerencji w samorzad miejski mieli właściciele miasta. Gubernator miał się zajmować wyłącznie sprawami Białegostoku. Do jego kompetencji należało ostateczne rozstrzyganie wszelkich spraw sądowych, przed nim składano apelację z sądów burmistrzowskich, landwójtowskich oraz kahalnych. Ponadto kontrolował on przestrzeganie przepisów przeciwpożarowych, sprawował nadzór nad handlem oraz dbał o dobra monetę (wykrywał gorsze jednostki monetarne wypuszczane do obiegu). Do jego zadań należał nawet nadzór nad wysokością pożyczek udzielanych przez szynkarzy na sprzedawane przez nich trunki. Ponadto pilnował on, aby majątki osób niemogących się wypłacić z zaciagniętych wierzytelności były zlicytowane ${ }^{27}$. Starano się również ograniczyć możliwość zaciagania kredytów przez stacjonujące w mieście wojsko. W tym celu gubernator Antoni Patyński, działając w imieniu Izabeli Branickiej, wydał 12 II 1779 r. zarządzenie zakazujące mieszkańcom miasta sprzedaży produktów na kredyt żołnierzom garnizonu ${ }^{28}$. Podobna intencja przyświecała kapitanowi Antoniemu Meyerowi, który 23 X 1785 r. wniósł do ksiag miejskich manifestację zabraniająca białostockim kredytodawcom udzielania pożyczek wojskowym z jego oddziału. Mogli oni zaciagnąć dług tylko gdy posiadali kartę $\mathrm{z}$ jego podpisem ${ }^{29}$. Wydaje się to logicznym posunięciem, zwłaszcza gdy przyjrzymy się zadłużeniu żołnierzy stacjonujacych w Białymstoku. Jednym z takich przykładów jest przypadek Andrzeja Bronkowskiego. W grudniu 1784 r. wpisano do ksiag miejskich listę jego wszystkich wierzycieli - był on winny tak chrześcijanom, jak i Żydom, w sumie 15 kredytodawcom, niebagatelną kwotę 1555 złp 1 gr. W celu spłacenia długów zrzekł się on swojej nieruchomości (dom wraz z placem) mieszczącej się przy ul. Zielonej ${ }^{30}$. Należy jednak wyraźnie zaznaczyć, że księgi miejskie nie uwzględniają pożyczek udzielanych wojskowym, którzy stanowili piąta część populacji miasta. Przeanalizowanie obrotu kredytowego z miejskim garnizonem wymaga oddzielnego opracowania, nie jest ono przedmiotem niniejszej analizy.

$\mathrm{Na}$ rolę gospodarczą danego miasta oddziaływały także stosunki ludnościowe. Literatura przedmiotu podaje, że na początku lat 70 . XVIII stulecia Białystok był jednym z większych ośrodków miejskich

${ }^{27}$ AP w Białymstoku, Teki Glinki, teka 122, s. 19-23, 121-122.

${ }^{28}$ K. Łopatecki, dz. cyt., s. 356.

${ }^{29}$ AGAD, Księgi miejskie białostockie, sygn. 3, s. 177.

30 Tamże, s. 154. 
Podlasia. Według Adama Dobrońskiego miasto zamieszkiwać miało około 3,5 tys. osób ${ }^{31}$. Z kolei zdaniem Karola Łopateckiego ośrodek ten liczył nieco ponad 2,5 tys. mieszkańców, z czego $41 \%$ stanowili chrześcijanie, $35,5 \%$ Żydzi, a $23,5 \% \dot{z}_{\text {zołnierze }}{ }^{32}$. Dla porównania dodajmy, że pobliski Tykocin w tym samym okresie zamieszkiwało 3 tys. osób, a Bielsk Podlaski liczył około 2,5 tys. mieszkańców ${ }^{33}$. Białystok na tle innych ówczesnych miast odznaczał się zróżnicowanym składem społeczno-zawodowym. Inwentarz z 1771/1772 r. wymienia około 120 zajęć wykonywanych w tym ośrodku ${ }^{34}$. Świadczy to o daleko posuniętej specjalizacji wśród białostoczan, która wynikała z charakteru omawianego miasta, pracującego na rzecz magnackiej rezydencji. Pod koniec XVIII w. w Białymstoku skupiało się około 400 rzemieślników (zarówno mistrzowie, czeladnicy, jak i uczniowie) różnych profesji ${ }^{35}$. Znacznie mniej liczna grupę stanowili kupcy - inwentarz wylicza tylko 34 osoby zajmujące się handlem, wyszynkiem oraz pośrednictwem. W głównej mierze byli to Żydzi ${ }^{36}$. Z kolei w 1800 r. urzędnicy pruscy naliczyli 37 kupców oraz 50 karczem $^{37}$, choć wydaje się, że ludność mogła nie podawać urzędnikom swoich rzeczywistych zawodów z obawy m.in. przed podniesieniem świadczeń podatkowych. Należy pamiętać, że Białystok nie był znaczacym ośrodkiem handlowym, podobnie jak inne miasta tej rangi stał się miejscem wymiany produktów rolnych, wytworów rzemieślniczych oraz towarów przywożonych przez kupców. Niektórzy białostoccy mieszczanie utrzymywali się także z zajęć rolniczych (uprawa ziemi oraz hodowla zwierzat) - Antoni Oleksicki w oparciu o inwentarz wylicza 39 takich osób, byli to chrześcijanie o polskobrzmiących nazwiskach. Jednak większa część mieszkańców Białegostoku posiadała na swoich działkach, obok budynków mieszkalnych, różnego rodzaju ogrody warzywne, sady oraz zabudowania gospodarcze, co świadczy o rolniczym charakterze miasta. Osobną grupę stanowili bojarzy, także utrzymujący się z pracy

31 A. Dobroński, Białystok. Historia miasta, Białystok 2001, s. 38.

${ }^{32}$ Należy zaznaczyć, że Białystok w XVIII w., z uwagi na siedzibę hetmana, był miastem garnizonowym oraz posiadał jak na ówczesne czasy silną załogę wojskowa; K. Łopatecki, dz. cyt., s. 351.

${ }^{33}$ W. Kusiński, Przemiany funkcji Białegostoku w przeszłości, „Rocznik Białostocki” 6, 1966, s. 272.

34 A. Oleksicki, Socjotopografia Białegostoku..., s. 41.

35 J. Maroszek, Rzemiosto $w$ miastach podlaskich $w$ XVI-XVIII $w$., w: M. Kwapień, J. Maroszek, A. Wyrobisz, Studia nad produkcja rzemieślniczq w Polsce (XIV-XVIII w.), Wrocław 1976, s. 186-187.

${ }^{36}$ A. Oleksicki, Socjotopografia Biategostoku..., s. 51.

37 J. Łukasiewicz, Biatystok w XIX wieku, w: Studia i materiaty do dziejów miasta Białegostoku, t. 3, red. J. Joka, Białystok 1972, s. 66. 
na roli. Posiadali oni własną ziemię, znajdująca się poza obrębem miasta. Kolejna grupa zawodową była służba dworska oraz oficjaliści, pełniący różne funkcje na dworze Branickich (inwentarz podaje 36 osób, które możemy zaliczyć do tej grupy, choć należy zaznaczyć, że znaczna część służby nie została w nim ujęta, mieszkała bowiem w rezydencji magnackiej) ${ }^{38}$.

Wykres 1. Liczba zapisów dotyczących transakcji kredytowych w Białymstoku w drugiej połowie XVIII w.

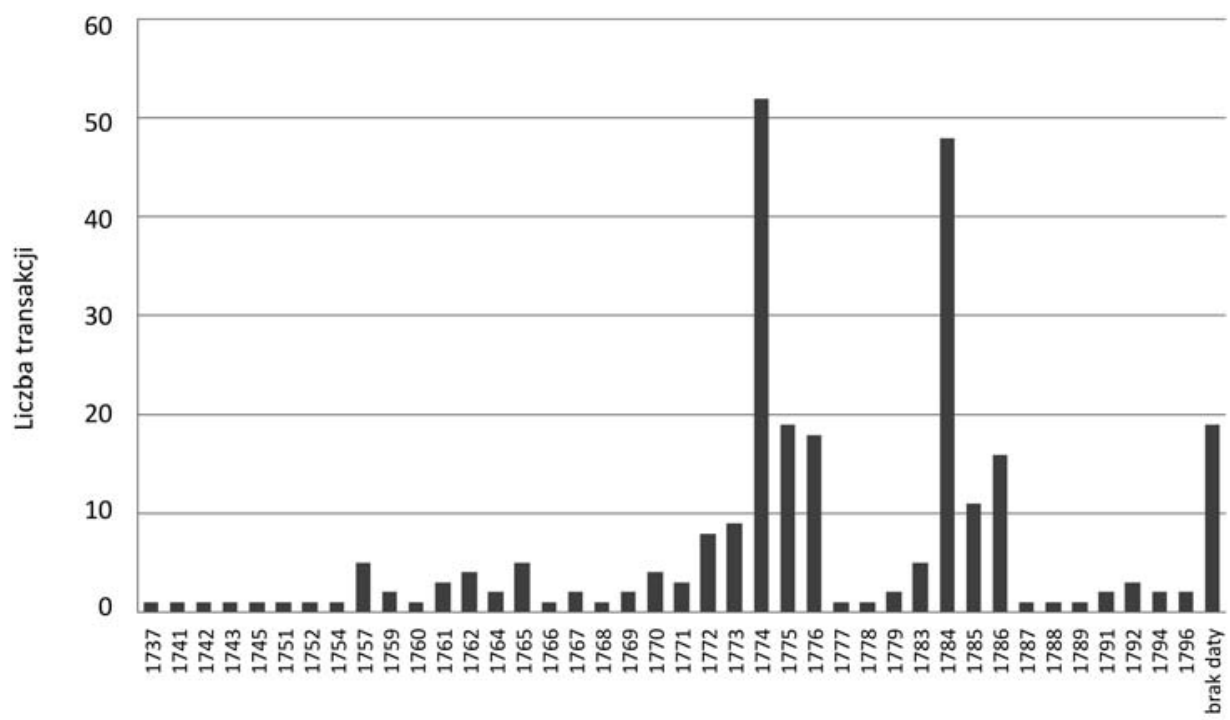

Źródło: AGAD, Księgi miejskie białostockie, sygn. 1-3, passim; AGAD, Archiwum Roskie, Akta osobisto-rodzinne i majątkowo-prawne, sygn. 628, 633, 634, 636, passim; AGAD, Archiwum Branickich z Białegostoku, sygn. 48, s. 27.

Pierwszym etapem analizy białostockiego rynku kredytowego jest zbadanie zagadnienia częstotliwości zapisów. $\mathrm{Z}$ zachowanych dokumentów udało się wyodrębnić 264 wpisy dotyczące umów pożyczkowych, zgłoszeń do otaksowania zastawionych dóbr czy wierzytelności zapisanych w testamentach (zob. wykres 1). Najwięcej transakcji odnotowano w latach 1772-1776 (zwłaszcza w 1774 r.) i 1784. Trzeba jednak zaznaczyć, że z lat 70. i 80. XVIII stulecia zachowało się najwięcej wpisów w księgach miejskich. Z kolei tak duża ich liczba w 1774 r. wiązała się ze sprawami spadkowymi po śmierci białostockiego kupca

38 A. Oleksicki, Socjotopografia Białegostoku..., s. 50, 52-53; tenże, Rozwój przestrzenny..., s. 73-74; I. Kulesza-Woroniecka, Wspótpracownicy Izabeli Branickiej w latach 1771-1808, „Studia Podlaskie” 20, 2012, s. 162. 
handlu zagranicznego Wolfa Gołdy (25 wpisów odnoszących się do jego wierzytelności), w $1784 \mathrm{r}$. zaś była wynikiem wciagnięcia do akt kwitu Andrzeja Bronkowskiego (był zadłużony u 15 białostockich kredytodawców) oraz długów krawca Józefa Jaworowskiego (17 zapisek). Podkreślić należy również fakt, iż w zachowanych księgach miejskich znalazła się jedynie część obrotów kredytowych. Do akt nie wciagano wszystkich transakcji. Świadczy o tym ta część wpisów, która dotyczy niespłaconych w terminie długów i zawiera zgłoszenie do otaksowania zastawionych ruchomości. Ponadto zapisanie danej transakcji w księgach sądowych wiazało się z koniecznością wnoszenia opłat notarialnych. Osoba, która chciała złożyć pozew, musiała zapłacić pisarzowi $6 \mathrm{gr}$, sądowi przed rozpoczęciem sprawy $12 \mathrm{gr}$, a po wydaniu dekretu dodatkowo jeszcze 1 złp. W przypadku, kiedy jedna ze stron składała apelację powinna uiścić opłatę w wysokości 12 gr (tyle samo płaciło się za wniesienie protestacji i manifestacji) ${ }^{39}$. Mogło się więc zdarzyć, że koszty notarialne związane z wpisaniem kwitu dłużnego do akt były równe lub wyższe od kwoty zadłużenia, dlatego też transakcje takie nie były wciagane do ksiąg miejskich. Należy również pamiętać, że część wierzytelności białostockich kupców mogła być wpisana do ksiag sądowych innych ośrodków miejskich, np. tych, z których pochodzili ich partnerzy biznesowi. W związku z tym pełna rekonstrukcja rynku kredytowego jest niemożliwa, ale poniższa analiza pozwala zorientować się w skali i charakterze zjawiska.

Ważnym elementem w badaniach nad gospodarka jest analiza koncentracji danego zjawiska w ramach poszczególnych grup zamożności. Niestety, dla 6\% transakcji nie posiadamy informacji o wielkości umowy kredytowej. Dane przedstawione w tabeli 1 pokazuja zaś, że aż 67,8\% wartości wszystkich umów pożyczkowych koncentrowało się w ręku nielicznej grupy osób (9\% spraw). W białostockim ruchu kredytowym liczebnie dominowały niewielkie transakcje (do $50 \mathrm{złp}-41 \%$ ), lecz ich wartość stanowiła margines obrotów (1,8\%). Również zadłużenia w wysokości 51-100 złp miały niewielki udział w rynku (2\%). Popularne były

${ }^{39}$ AGAD, Księgi miejskie białostockie, sygn. 2, s. 90. Opłaty notarialne w białostockim sądzie miejskim nie były jednak wygórowane. Wyższe obciążenia odnotowano m.in. w mniejszych miastach Prus Królewskich. Przykładowo w Sztumie od każdej sesji urzędu pobierano 24 gr, wydanie decyzji/orzeczenia kosztowało kolejne 36 gr, wniesienie apelacji 4 floreny i 12 gr (132 gr), kwitancja zaś (np. dłużnika) - 24 gr. Z kolei w Chojnicach sesja urzędu wiązała się z kosztem 2 florenów (60 gr), protestacja - 1 florena (30 gr), apelacja - 2 florenów; zob. P. Kitowski, Opłaty sqdowe w mniejszych miastach Prus Królewskich w XVIII wieku, „Studia Historica Gedanensia” 6, 2015, s. $57-62$. 
także pożyczki średniej wielkości (101-500 złp), ich wartość wynosiła 13,4\% całego ruchu kredytowego. Jednakże największym zainteresowaniem cieszyły się transakcje do $100 \mathrm{złp} \mathrm{-} \mathrm{łącznie} \mathrm{stanowiły} \mathrm{one} \mathrm{52 \%}$ liczby wszystkich kontraktów, a ich wartość nie przekraczała $4 \%$ całości. W Białymstoku dominowały więc drobne pożyczki konsumpcyjne, choć istniał też duży kredyt, jednak jego udział w ogólnej strukturze rynku był dość niski.

Tabela 1. Struktura wartości obrotów rynku kredytowego w Białymstoku w drugiej połowie XVIII w.

\begin{tabular}{l|r|r|r|r|r|r|r}
\hline $\begin{array}{c}\text { Wartość } \\
\text { (w złp) }\end{array}$ & Do 50 & $\mathbf{5 1 - 1 0 0}$ & $\mathbf{1 0 1 - 5 0 0}$ & $\mathbf{5 0 1 - 1 0 0 0}$ & $\begin{array}{c}\text { Powyżej } \\
\mathbf{1 0 0 0}\end{array}$ & $\begin{array}{c}\text { Wartość } \\
\text { nieznana }\end{array}$ & Ogółem \\
\hline Liczba transakcji & 108 & 29 & 64 & 23 & 25 & 15 & 264 \\
\hline Wartość transakcji & 2142 & 2400 & 15991 & 18007 & 81115 & - & 119655 \\
\hline \% liczby & 41 & 11 & 24 & 9 & 9 & 6 & 100 \\
\hline \% wartości & 1,8 & 2 & 13,4 & 15 & 67,8 & - & 100 \\
\hline
\end{tabular}

Legenda: a) wartość transakcji przeliczona na złote polskie na podstawie: Z. Żabiński, Systemy pieniężne na ziemiach polskich, Wrocław 1981, s. 132 (tab. 78), 138 (tab. 81).

Źródło: AGAD, Księgi miejskie białostockie, sygn. 1-3, passim; AGAD, Archiwum Roskie, Akta osobisto-rodzinne i majątkowo-prawne, sygn. 628, 633, 634, 636, passim; AGAD, Archiwum Branickich z Białegostoku, sygn. 48, s. 27.

Pewnym ułatwieniem $\mathrm{w}$ określeniu wagi danego zadłużenia jest poznanie siły nabywczej pieniądza, którym obracali białostoccy mieszczanie w drugiej połowie XVIII stulecia (zob. tab. 2). Okazuje się to również pomocne w wyodrębnieniu kredytu konsumpcyjnego i inwestycyjnego.

$\mathrm{Na}$ podstawie zawartych w źródle cen nieruchomości i wynagrodzeń ${ }^{40}$ można umownie przyjaćc, że pożyczka konsumpcyjna charakteryzowała się niewielkimi sumami, poniżej $100 \mathrm{złp,} \mathrm{a} \mathrm{więc} \mathrm{kwoty} \mathrm{nie-}$ zbędnej do zakupu najtańszych nieruchomości miejskich ${ }^{41}$. Tego rodzaju transakcje rzadko były wpisywane do ksiag miejskich, gdyż umieszczenie ich w dokumentacji miejskiej wiązało się z koniecznością wnoszenia opłat notarialnych, które czasem mogły być równe, a nawet wyższe niż kwota zadłużenia. W niniejszych badaniach przyjęto, że drobniejsze formy kredytu inwestycyjnego zamykały się między 100 a 500 złp. Z kolei

${ }^{40}$ Przedstawione w niniejszym opracowaniu wynagrodzenia sa jedynie szacunkowe. Nie uwzględniają one wszystkich możliwych źródeł dochodów, a jedynie te uchwytne w zachowanych źródłach.

${ }^{41}$ Kwota 100 złp wystarczyła już na zakup drewnianego budynku wraz z placem; AGAD, Księgi miejskie białostockie, sygn. 3, s. 10. 
sumy większe niż 500 złp były związane z wielkim handlem oraz transakcjami kupna-sprzedaży zagranicznych towarów. Przykładem takiej pożyczki jest seria transakcji kredytowych wynikająca z założenia spółki handlowej przez Palitera Dawidowicza (białostockiego kupca i faktora) oraz Jana Aleksandra Lindsaya (majora regimentu piechoty buławy Wielkiej Koronnej). W 1761 i 1762 r. Dawidowicz, za poręczeniem Lindsaya, pożyczył od stolnika ziemi bielskiej Kruszewskiego 2500 tynfów (3166 złp 20 gr), ekonoma dobrzyniewskiego Biernackiego - 600 tynfów (720 złp) i 1421 tynfów (1705 złp 6 gr) od Dzierżyńskiego. Pieniądze te przeznaczone zostały na zakup towarów w Toruniu ${ }^{42}$. Z kolei na kwotę 865 złp u Nachmena Gołdy zadłużył się Wolf Gołda. Dług ten również zaciagnięto na zakup towarów ${ }^{43}$.

Tabela 2. Wynagrodzenia w Białymstoku w drugiej połowie XVIII w.

\begin{tabular}{l|c|c|l}
\hline \multicolumn{1}{|c|}{ Funkcja/zawód } & $\begin{array}{c}\text { Kwota roczna } \\
\text { wynagrodze- } \\
\text { nia (w złp) }\end{array}$ & Rok & \multicolumn{1}{c}{ Źródło } \\
\hline Felczer & $2160^{\mathrm{a}}$ & 1796 & $\begin{array}{l}\text { AGAD, Archiwum Branickich z Białego- } \\
\text { stoku, sygn. 8, s. 67 }\end{array}$ \\
\hline Kuchmistrz & $1512^{\mathrm{a}}$ & 1773 & Tamże, s. 15 \\
\hline Gubernator & $504^{\mathrm{a}}$ & 1774 & Tamże, s. 22 \\
\hline Landwójt & $432^{\mathrm{a}}$ & 1774 & Tamże, s. 22 \\
\hline $\begin{array}{l}\text { Dozorczyni fabryki } \\
\text { płóciennej }\end{array}$ & 400 & 1793 & $\begin{array}{l}\text { AGAD, Archiwum Roskie, Akta oso- } \\
\text { bisto-rodzinne i majątkowo-prawne, } \\
\text { sygn. 651, s. 11 }\end{array}$ \\
\hline Cieśla & $250^{\mathrm{b}}$ & 1788 & Tamże, sygn. 645, s. 13 \\
\hline Murarz & $250^{\mathrm{b}}$ & 1788 & Tamże, s. 10, 11. \\
\hline Cyrulik & $144^{\mathrm{a}}$ & $1773 / 1774$ & $\begin{array}{l}\text { AGAD, Archiwum Branickich z Białego- } \\
\text { stoku, sygn. 8, s. 15, 24 }\end{array}$ \\
\hline Praczka & $144^{\mathrm{a}}$ & $1773 / 1774$ & Tamże, s. 15, 24 \\
\hline Pomocnik budowlany & $125^{\mathrm{b}}$ & 1787 & $\begin{array}{l}\text { AGAD, Archiwum Roskie, Akta oso- } \\
\text { bisto-rodzinne i majątkowo-prawne, } \\
\text { sygn. 645, s. 2, 3, 7 }\end{array}$ \\
\hline
\end{tabular}

Legenda: a) płaca wyliczona na podstawie miesięcznych pensji (lafa i strawne) wypłacanych osobom pracujaccym na dworze Izabeli Branickiej; b) płaca wyliczona na podstawie dziennego wynagrodzenia. W obliczeniach przyjęto 250 dni pracy w roku.

${ }^{42}$ Założenie spółki handlowej zakończyło się fiaskiem. Towary zakupione w Toruniu przez Dawidowicza Lindsay zarekwirował, a następnie sprzedał we Lwowie. W związku z czym Żyd domagał się zwrotu poniesionych kosztów; AGAD, Archiwum Roskie, Akta osobisto-rodzinne i majątkowo-prawne, sygn. 634, s. 1, 3, 11, 83.

${ }^{43}$ AGAD, Księgi miejskie białostockie, sygn. 3, s. 101. 
W treści umów pożyczkowych na ogół nie podawano przyczyny zaciągnięcia długu. Najczęściej pojawia się tylko lakoniczne sformułowanie, że kredytobiorca pożyczał „na pilna potrzebę” bądź „dla własnej potrzeby", uniemożliwiające poznanie celu pożyczki. Rzadko do ksiag wpisywano szczegółowe kontrakty, ale i wówczas nie jest łatwo scharakteryzować pożyczkę jako jednoznacznie konsumpcyjna. Do takiej transakcji doszło w marcu 1776 r., kiedy Michał Szczyt pożyczył w sumie 256 złp 1 gr Gotlibowi Brasmanowi, który kwotę tę przeznaczył na śledzie, mięso oraz różnego rodzaju trunki ${ }^{44}$. Z kolei Dawidowa Abramowiczowa 16 X $1783 \mathrm{r}$. oddała kwote 28 złp zaciagniętą u Protasiewicza na zakup krowy ${ }^{45}$. Natomiast 18 I 1774 r. Antonowa Wroczyńska, wdowa po landwójcie Białegostoku, pożyczyła od Krystyny Giergielewiczowej 90 złp, które miały posłużyć do spłaty długów zmarłego męża ${ }^{46}$. Nie jest to jedyna sytuacja, kiedy żona musiała regulować zobowiąania nieżyjącego współmałżonka. W 1791 r. Eleonora Kozłowska, wdowa po majorze Janie Kozłowskim, starała się odzyskać od podpułkownika Kadłubskiego pieniądze pożyczone mu przez jej męża, aby następnie spłacić jego wierzycieli ${ }^{47}$.

$\mathrm{Z}$ analizowanych umów kredytowych wynika, że pożyczek udzielała w większości ludność o polskobrzmiących nazwiskach - stanowili oni około 51,5\% kredytodawców. Wielu z nich również zaciagało zobowiązania (stanowili 51\% dłużników). Jedna czwarta wszystkich transakcji kredytowych odbywała się w obrębie ludności o polskobrzmiących nazwiskach. Były to w przeważającej większości drobne pożyczki, w wysokości nawet od 4 złp, choć spotykamy też wierzytelności wielokrotnie większe, rzędu przeszło 300 złp.

Pieniądze pożyczali także białostoccy Żydzi, stanowili oni 31\% wszystkich wierzycieli w kontraktach zapisanych w księgach miejskich. Możemy jednak przypuszczać, że ich rzeczywisty udział w rynku kredytowym był znacznie większy, gdyż część transakcji starozakonnych wciagano do ksiag kahalnych, które niestety się nie zachowały. Do nich musiały trafiać przede wszystkim umowy kredytowe zawierane między Żydami. Wpisy źródłowe nie wskazują również, aby bankierzy czy kupcy żydowscy pożyczali pieniądze duchowieństwu, co zdarzyło się kilkakrotnie w Zamościu (w drugiej połowie XVII w.) ${ }^{48}$ i Tomaszowie

44 Tamże, s. 111.

45 Tamże, s. 126.

46 Tamże, s. 47-48.

${ }^{47}$ AGAD, Archiwum Roskie, Akta osobisto-rodzinne i majatkowo-prawne, sygn. 636 , s. 20-34.

${ }^{48}$ J. Morgensztern, dz. cyt., s. 6-7. 
Lubelskim (w XVIII stuleciu) ${ }^{49}$. Podobnie jak w innych miastach podlaskich (Goniądzu, Kleszczelach czy Orli ${ }^{50}$ ), udzielanie kredytu na procent było zapewne podstawowym źródłem utrzymania wielu członków białostockiej gminy żydowskiej. Niewielkie sumy pod zastaw ruchomości pożyczał kupiec Morthaj Leybowicz, jego dłużnikami byli m.in. Franciszek Luniewski, Złotoszewski, Godziarz czy kucharz Jędrzej ${ }^{51}$. $\mathrm{Z}$ drugiej strony z wpisów wnoszonych do ksiag miejskich możemy się dowiedzieć, że białostockim kredytodawca był również bogaty kupiec handlu dalekosiężnego Wolf Gołda, któremu różni miejscowi dłużnicy, zarówno chrześcijanie, jak i Żydzi, byli winni w sumie aż 4417 złp 5 gr (2585 złp 27,5 gr - zapisane na skryptach dłużnych, 1831 złp 7,5 gr - długi zapisane w księdze kupieckiej) ${ }^{52}$. Zazwyczaj jednak wysokość udzielanych mieszczanom kredytów nie przekraczała 100 złp. Wierzytelności zaciagane przez mieszkańców Białegostoku u Izraelitów przeznaczane były na cele konsumpcyjne, czasem wręcz na zaspokojenie niezbędnych potrzeb. Nie było to zjawisko nadzwyczajne, w niedalekim Tykocinie standardowa kwota pożyczana przez Żydów wynosiła około $50 \mathrm{złp}^{53}$. Księgi sądowe potwierdzają również, że starozakonni korzystali z kredytu pieniężnego u mieszczan (Izraelici stanowili 22\% kredytobiorców). Dłużnikami chrześcijan byli m.in. kupcy oraz kahał. Przykładowo w 1776 r. członkowie gminy żydowskiej pożyczyli od Andrzeja i Marianny Protasiewiczów 600 złp $^{54}$, a w latach 90. od niejakiego Łosiewskiego 502 złp 15 gr $^{55}$. Również wspomniany wcześniej kupiec Wolf Gołda był winny wielu chrześcijańskim kredytodawcom niebagatelną sumę 11609 złp 20 gr $^{56}$. Izraelici zaciagali także zobowiązania pieniężne u właścicieli miasta. W 1742 r. rzeźnicy Hazyl Abramowicz, Abram Markowicz i Jankiel Aronowicz pożyczyli od Jana Klemensa Branickiego kwotę 25 czerwonych złotych, która zobowiązali się oddać $ł_{\text {łojem }}^{57}$. Z kolei białostocki kahał zadłużył się u Izabeli Branickiej na

${ }^{49}$ E. Hanejko, Miasto w okresie od wielkiego sporu o Ordynację do I rozbioru Polski, w: Tomaszów Lubelski. Monografia miasta, red. R. Szczygieł, Lublin-Tomaszów Lubelski 2011, s. 148.

${ }^{50}$ A. Leszczyński, dz. cyt., s. 190.

${ }^{51}$ AGAD, Księgi miejskie białostockie, sygn. 3, s. 88-89.

${ }^{52}$ Tamże, s. 101.

53 A. Leszczyński, dz. cyt., s. 190.

${ }^{54}$ AGAD, Księgi miejskie białostockie, sygn. 3, s. 113-114.

55 AGAD, Archiwum Roskie, Akta osobisto-rodzinne i majątkowo-prawne, sygn. 633, s. 68-69.

${ }^{56}$ AGAD, Księgi miejskie białostockie, sygn. 3, s. 77.

57 AGAD, Archiwum Roskie, Akta osobisto-rodzinne i majątkowo-prawne, sygn. 633 , s. 3 . 
łączną sumę 2344 złp 10 gr, którą gmina żydowska przeznaczyła na spłatę dawnych długów ${ }^{58}$.

W obrocie kredytowym udział brały także kobiety. Były one zarówno dłużniczkami, jak i wierzycielkami. Z zapisów wynika, że dwa razy więcej niewiast pożyczało własne pieniądze innym (41 wpisów), niż się zadłużało (20 wpisów). Kredyty zaciagały w głównej mierze chrześcijanki, zazwyczaj na niewielkie kwoty (poniżej 100 złp). Możemy przypuszczać, że były to wdowy, których sytuacja materialna po śmierci męża uległa pogorszeniu. Sporadycznie zdarzały się również większe transakcje. Przykładowo 23 V 1757 r. urząd miejski przystapił do taksy domu przy ul. Suraskiej (nieruchomość wyceniono na kwotę 410 tynfów, czyli 519 złp 10 gr) za niespłacony dług pani Pryslowej, który wynosił 40 czerwonych złotych $(720 \mathrm{złp})^{59}$. Z kolei 23 IX 1776 r. białostocka rabinowa Rejza zaciągnęła kredyt w wysokości 200 złp u kupca Andrzeja Chalewicza z Królewca ${ }^{60}$. Kobiety były jednak przede wszystkim kredytodawcami, zdarzało się, że bardzo poważnymi. W czerwcu $1774 \mathrm{r}$. Zuzanna Podolińska pożyczyła kahałowi białostockiemu 600 złp, z których to gmina zobowiązała się wypłacać rocznie 48 złp odsetek ${ }^{61}$. Kahał zadłużony był również u kominiarki Franciszkowej - na kwotę 230 złp i wypłacał jej co roku 23 złp prowizji, a fontaniścinie, od kwoty $1000 \mathrm{złp}$, płacił 80 złp odsetek rocznie ${ }^{62}$. Z kolei Ewa Grogulecka z pożyczonej w czerwcu 1776 r. kwoty 900 złp otrzymywała co roku 90 złp odsetek, a z innego udzielonego kredytu, na sumę 414 złp, uzyskiwała 18 złp rocznej prowizji ${ }^{63}$. Te dosyć poważne sumy kontraktów wskazuja, że część kobiet utrzymywała się z odsetek od posiadanego kapitału, udzielając pożyczek innym mieszkańcom miasta.

Badany materiał źródłowy zawiera jednak niepełne dane dotyczące stopy procentowej od udzielanego kredytu. Jedynie w 40 wpisach podano takie informacje. Na ich podstawie możemy obliczyć, że dłużnicy płacili rocznie średnio $8 \%$ odsetek od pożyczonej sumy (najniższe oprocentowanie wynosiło $5 \%$, najwyższe zaś $12,5 \%)^{64}$. Jest to stosunkowo wysoka stopa procentowa, także w odniesieniu do konstytucji sejmowej z 1775 r., zatytułowanej „Ustanowienie prowizyi, y ubeśpieczenie kredytorow”.

58 Tamże, s. 68, 71.

${ }^{59}$ AGAD, Księgi miejskie białostockie, sygn. 1, s. 48.

60 Tamże, sygn. 3, s. 118.

${ }^{61}$ Tamże, s. 73-74.

62 AGAD, Archiwum Roskie, Akta osobisto-rodzinne i majątkowo-prawne, sygn. 633, s. 68-69.

${ }^{63}$ AGAD, Księgi miejskie białostockie, sygn. 3, s. 103-104.

${ }^{64}$ Tamże, sygn. 2-3, passim; AGAD, Archiwum Roskie, Akta osobisto-rodzinne i majatkowo-prawne, sygn. 633-634, passim. 
Wprowadziła ona bowiem ograniczenia dla transakcji kredytowych, które nie powinny mieć większego oprocentowania niż 5\% w skali roku. Osoby lub instytucje udzielające pożyczek na wyższy procent traciły prowizję i musiały zapłacić karę w wysokości 500 grzywien. Z kolei kredytobiorca w przypadku zaległości płatniczych był zobligowany do zapłacenia karnych odsetek w wysokości 7\%. Regulacje te miały wsteczna moc obowiązująca (od 1768 r.), nie dotyczyły jednak kredytów udzielanych pod zastaw nieruchomości ${ }^{65}$. Podobne do białostockich oprocentowanie pożyczek odnotowano również w innych miastach. Przykładowo w Tomaszowie Lubelskim w XVIII stuleciu w większości przypadków odsetki od udzielonego kredytu wynosiły $7-8 \%{ }^{66}$. W Nowym Sączu na przełomie XVI i XVII w. roczna stopa procentowa sięgała 10\% (w przypadku kredytów zabezpieczanych zastawem nieruchomości nawet $10-15 \%)^{67}$. Natomiast $\mathrm{w}$ siedemnastowiecznym Toruniu uiszczano $6 \%$ odsetek od udzielonego kredytu (oprocentowanie wahało się od 4 do maksymalnie $8 \%{ }^{68}$. Z kolei na Żuławach Wiślanych na przełomie XVII i XVIII stulecia mieszczanie i chłopi płacili nie więcej niż 8,5\% odsetek, a w XVIII w. nawet $3 \%{ }^{69}$. Również w sasiednim Tykocinie roczne oprocentowanie wynosiło około $8 \%{ }^{70}$.

Trudno jest również ustalić dokładny termin zaciagnięcia i spłaty wierzytelności, gdyż duża część wpisów dotyczy zgłoszenia do otaksowania zastawionych ruchomości za niespłacone w terminie długi. Ponadto część zapisów uwzględnia także wierzytelności z okresów wcześniejszych. Wydaje się jednak, że umowy pożyczkowe zawierano głównie w okresie od kwietnia do czerwca, co wiązało się z niedoborem żywności i gotówki. Z kolei ustalony dzień spłaty często przypadał na okres trwania jarmarku na św. Jana Chrzciciela ${ }^{71}$. Był to największy białostocki jarmark (pozostałe cztery nie cieszyły się większym powodzeniem), organizowany w dniu imienin właściciela miasta. Także sam Jan Klemens Branicki czynił starania o nadanie mu rozgłosu i ściagnięcie kupców m.in. z Warszawy ${ }^{72}$.

${ }^{65}$ Volumina legum, t. 8, Petersburg 1860, s. 112-113.

${ }^{66}$ E. Hanejko, dz. cyt., s. 148.

67 A. Dunin-Wasowicz, dz. cyt., s. 65, 72.

68 A. Mycio, Formy kredytu mieszczańskiego na poczatku XVII wieku w świetle ksiag ławniczych Starego Miasta Torunia, „Rocznik Toruński” 26, 1999, s. 65.

${ }^{69}$ P. Szafran, dz. cyt., s. 144.

70 A. Leszczyński, dz. cyt., s. 198.

71 AGAD, Księgi miejskie białostockie, sygn. 3, s. 26, 49, 73-74; AGAD, Archiwum Roskie, Akta osobisto-rodzinne i majątkowo-prawne, sygn. 633, s. 30-33, 54-56.

${ }^{72}$ A. Sztachelska-Kokoczka, Handel $w$ miastach dóbr podlaskich Jana Klemensa Branickiego, w: Miasto, region, społeczeństwo. Studia ofiarowane profesorowi Andrzejowi Wyrobiszowi w sześćdziesiata rocznicę Jego urodzin, red. E. Dubas-Urwanowicz, J. Urwanowicz, Białystok 1992, s. 105. 
Wykres 2. Umowy kredytowe w zależności od długości trwania (w latach) w Białymstoku w drugiej połowie XVIII w.

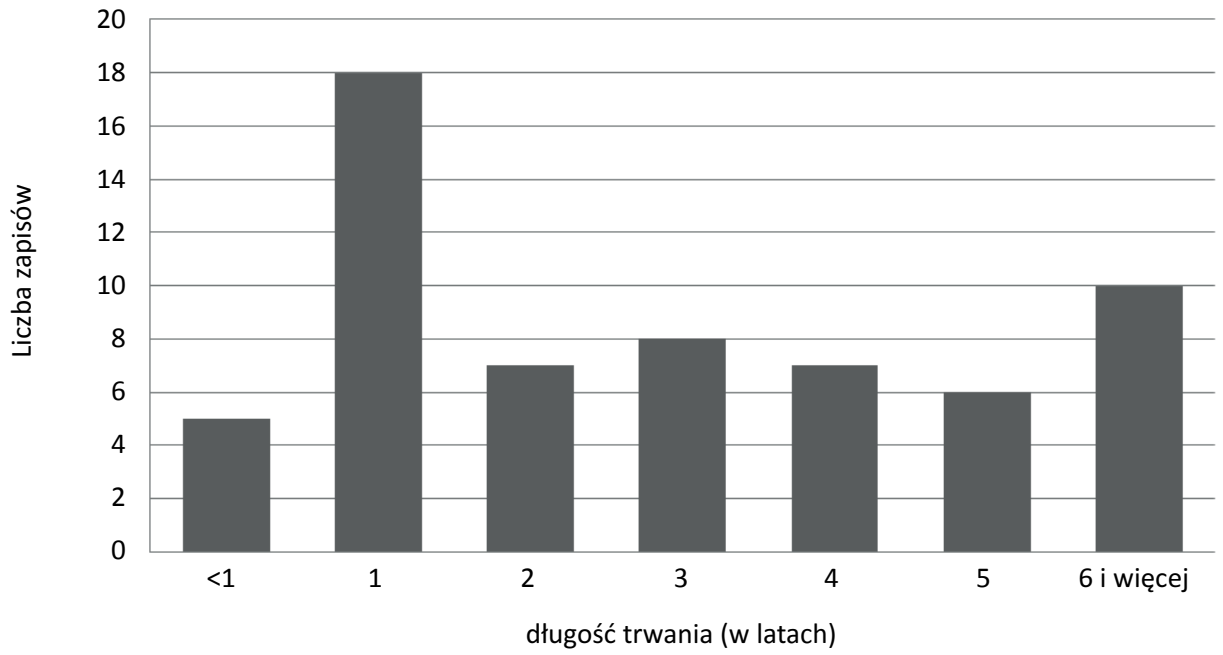

Źródło: AGAD, Księgi miejskie białostockie, sygn. 1-3, passim; AGAD, Archiwum Roskie, Akta osobisto-rodzinne i majątkowo-prawne, sygn. 633, 636, passim.

Wykres 3. Dodatkowy sposób zabezpieczania umów kredytowych w Białymstoku w drugiej połowie XVIII w.

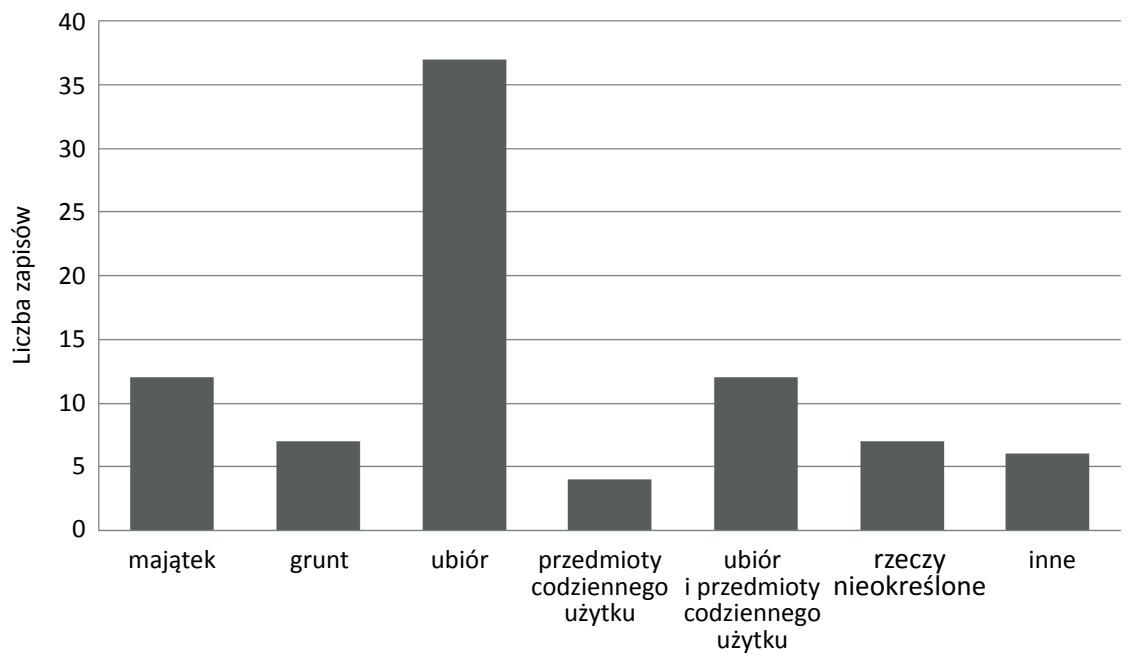

Źródło: AGAD, Księgi miejskie białostockie, sygn. 1-3, passim; AGAD, Archiwum Roskie, Akta osobisto-rodzinne i majątkowo-prawne, sygn. 633, 634, passim; AGAD, Archiwum Branickich z Białegostoku, sygn. 48 , s. 27. 
Wszelkiego rodzaju operacje kredytowe wiążą się z ryzykiem utraty pożyczonych pieniędzy. W związku z tym wypracowano rozmaite sposoby asekuracji umów pożyczkowych. W przypadku Białegostoku 32\% transakcji (85 zapisek) oprócz samego kwitu dłużnego czy wpisu do ksiag sądowych zostało opatrzone dodatkową formą zabezpieczenia (zob. wykres 3).

Najczęściej spotykanymi zastawami w Białymstoku były ubiory męskie i damskie (kontusze, żupany, spódnice, kamizelki, czapki, spodnie, chusty, pasy, surduty) ${ }^{73}$. Zabezpieczenie długu stanowiły również przedmioty codziennego użytku (np. półmiski, misy oraz talerze cynowe, łyżki i noże, mosiężne żelazko do prasowania, srebrny dzbanek, kubki) ${ }^{74}$. Z kolei na swoich nieruchomościach oraz całym majątku gwarancji wierzycielom udzielali głównie Żydzi, rzadziej chrześcijanie. Jeżeli zaś dłużnikiem był zarząd kahału, to cała gmina solidarnie ręczyła za udzielona pożyczkę. Ponadto wierzycielom zastawiono takie przedmioty jak skrzypce ${ }^{75}, 4$ obrazki oprawione w szkło ${ }^{76}$, kulbakę ${ }^{77}$, zegar $^{78}$, pistolety francuskie ${ }^{79}$ czy przyrządy liturgiczne (Korona Tory, wskaźnik do czytania Tory, tzw. jad) ${ }^{80}$. Kredytodawca mógł sprzedać rzeczy będące zabezpieczeniem umowy pożyczkowej w sytuacji niespłacenia długu w ustalonym terminie. W takim przypadku wierzyciel powinien przedmioty te zgłosić do otaksowania w urzędzie miejskim. Czynność taka przeprowadzał sprowadzony specjalista w danej dziedzinie (przykładowo ubiory wyceniał krawiec, drewniany dom - cieśla). Po otaksowaniu magistrat wzywał dłużnika do uregulowania wierzytelności i wykupienia zastawu, przeważnie w ciagu 30 dni. W przypadku wyceny zastawionych rzeczy powyżej kwoty długu kredytodawca po sprzedaży przedmiotów powinien tę nadwyżkę zwrócić do urzędu. Jeżeli zaś zastaw otaksowano poniżej wartości zaciagniętej pożyczki, to wierzyciel ponosił straty $^{81}$. Zdarzało się również, że sąd miejski po wycenie zastawu kazał kredytobiorcy odpracować brakującą część długu ${ }^{82}$. Z wpisów zawartych

${ }^{73}$ AGAD, Księgi miejskie białostockie, sygn. 1, s. 19, 29, 93a; tamże, sygn. 3, passim.

${ }^{74}$ Tamże, sygn. 3, s. 64, 87-89, 94.

75 Tamże, s. 180.

76 Tamże, s. 166-167.

77 Tamże, s. 153.

78 Tamże, s. 8.

${ }^{79}$ AGAD, Księgi miejskie białostockie, sygn. 1, s. 49.

80 AGAD, Archiwum Roskie, Akta osobisto-rodzinne i majątkowo-prawne, sygn. 633 , s. $30-33$.

${ }^{81}$ AGAD, Księgi miejskie białostockie, sygn. 3, s. 75, 87-89, 110-111, 124, 129, 143, 153, 170, 180.

${ }^{82}$ Tamże, s. 75. 
Wykres 4. Wartości pożyczek zaciagniętych w Białymstoku w drugiej połowie XVIII w. w zależności od dodatkowego sposobu ich zabezpieczania ('średnia arytmetyczna)

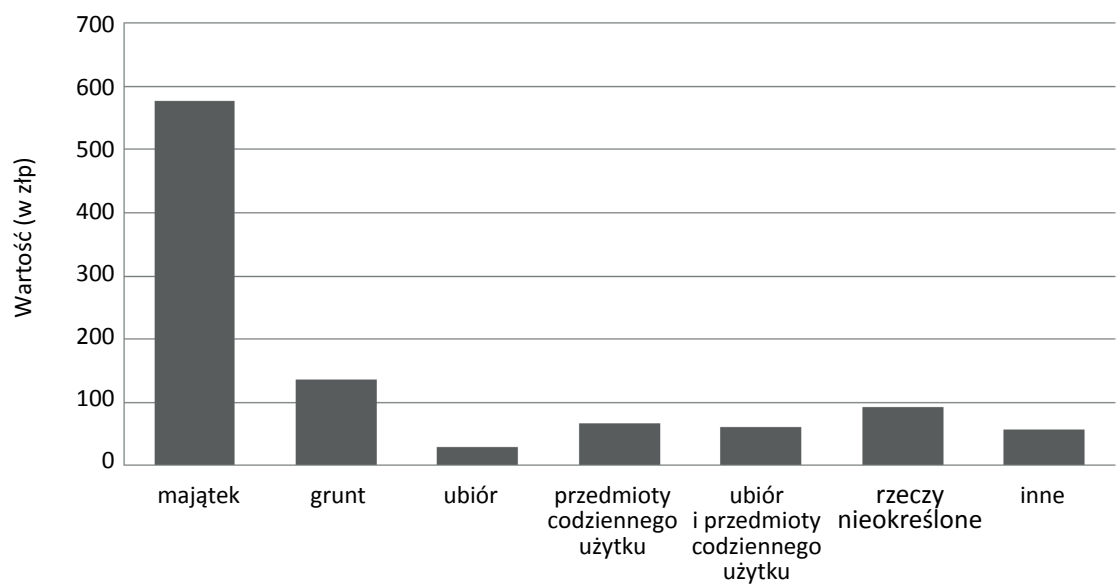

Źródło: AGAD, Księgi miejskie białostockie, sygn. 1-3, passim; AGAD, Archiwum Roskie, Akta osobisto-rodzinne i majątkowo-prawne, sygn. 633, 634, passim; AGAD, Archiwum Branickich z Białegostoku, sygn. 48 , s. 27.

w zachowanych księgach miejskich wynika również, że niektórzy Żydzi prowadzili w Białymstoku działalność lombardowa.

Wiedząc, jakie były sposoby zabezpieczania kredytu, należałoby się jeszcze przyjrzeć wysokości pożyczek osiagniętej w każdej z wyróżnionych grup zastawów (wykres 4). Widać wyraźnie, że wielkość zabezpieczenia zależała od wysokości zaciaganego długu. Na drobne zadłużenia gwarancji udzielano poprzez zastawienie ubioru i innych ruchomości (do $100 \mathrm{złp).} \mathrm{Nieco} \mathrm{większe} \mathrm{zabezpieczano} \mathrm{już} \mathrm{na} \mathrm{nieruchomościach} \mathrm{-}$ przeważnie na gruncie. Natomiast duże kredyty asekurowano zapisem dotyczacym całego majątku. Podobnie rzecz wyglądała w innych miastach. W Tomaszowie Lubelskim znaczne sumy zabezpieczano zazwyczaj na nieruchomościach, na mniejsze zaś udzielano gwarancji na różnych przedmiotach, czasem nawet odzieży, jednakże nie była ona tak częstym przedmiotem zastawów jak w Białymstoku ${ }^{83}$. Z kolei nowosadeccy mieszczanie na przełomie XVI i XVII w. udzielali pożyczek zabezpieczanych w głównej mierze (85,1\% transakcji) skryptem dłużnym lub rękojemstwem, jedynie 9,3\% transakcji zabezpieczano poprzez zastaw nieruchomości, resztę zaś zastawem rzeczy ruchomych ${ }^{84}$.

Jeżeli zaś pożyczka nie została oddana w ustalonym czasie, a umowa nie była zabezpieczona zastawem, mogło dojść do przejęcia majątku

${ }^{83}$ E. Hanejko, dz. cyt., s. 148.

${ }^{84}$ A. Dunin-Wasowicz, dz. cyt., s. 65. 
kredytobiorcy bądź odpowiedniej do skali długu jego części. W księgach miejskich zachowało się dziesięć takich wpisów. Do tego rodzaju sytuacji doszło 5 X 1764 r., kiedy wniesiono ,areszt” na piekarnię Szymona Bieleckiego, który nie był wstanie spłacić pożyczki zaciąniętej u Jakuba Sadowskiego ${ }^{85}$. Natomiast w kwietniu 1774 r. Franciszek Matelski, rewizor dóbr podlaskich, po sprawie spornej o zwrot 2700 złp przeciw małżeństwu Boćkowskim na podstawie wyroku sądu miejskiego stał się właścicielem ich domu leżącego przy ul. Tykockiej oraz kramu usytuowanego na białostockim rynku ${ }^{86}$. Z kolei magistrat w grudniu $1774 \mathrm{r}$. zlicytował poduszki, poszewki i ręczniki należące do Johanowej Młynarskiej. Była ona winna Słowiańskiemu, rzeźnikowi białostockiemu, 6 złp $15 \mathrm{gr}^{87}$. Ostatni z przytoczonych przykładów pokazuje, że w sądzie miejskim upominano się o zwrot nie tylko znacznych kwot, ale równie bardzo niskich sum. Może to świadczyć o skromnej sytuacji majątkowej niektórych mieszkańców miasta.

Niekiedy pożyczka była spłacana w ratach. Zjawisko to jest jednak trudne do uchwycenia, gdyż białostockie księgi miejskie bardzo rzadko odnotowywały spłaty poszczególnych rat. $\mathrm{O}$ takich operacjach dowiadujemy się najczęściej dopiero przy okazji zwrotu ostatniej części długu i kwitancji obu stron. Przy tak małej liczbie spraw nie da się ustalić zależności zachodzących pomiędzy liczbą rat a wysokością zadłużenia oraz odpowiedzieć na pytanie, czy rozłożenie płatności na kilka części wpływało na długość umowy pożyczkowej, choć możemy przypuszczać, że obie znane $\mathrm{z}$ innych rynków kredytowych tendencje funkcjonowały także w Białymstoku.

$$
* * *
$$

Analiza zawartości najstarszych białostockich ksiag sądowych wskazuje, że ważnym przejawem aktywności gospodarczej mieszczan były operacje kredytowe. Pożyczki wykorzystywano nie tylko w obrotach towarowych i inwestycjach, ale przede wszystkim w celach konsumpcyjnych. Białostocki rynek kredytowy w głównej mierze opierał się na kontraktach o niewielkiej wartości (do 100 złp), przeważnie zaciaganych na rok, choć większość transakcji nie miała określonego terminu spłaty. Duża część wierzytelności była także dodatkowo zabezpieczona

${ }^{85}$ AGAD, Księgi miejskie białostockie, sygn. 1, s. 85.

${ }^{86}$ Tamże, sygn. 2, s. 59-60; AGAD, Archiwum Roskie, Akta osobisto-rodzinne i majątkowo-prawne, sygn. 633, s. 34-39.

${ }^{87}$ AGAD, Księgi miejskie białostockie, sygn. 3, s. 89. 
poprzez zastaw, którego wartość zależała od wielkości długu. Należy również zaznaczyć, że na rozwój operacji kredytowo-pieniężnych badanego ośrodka znacząco wpłynęli także Żydzi, którzy według danych zawartych w zachowanych źródłach stanowili co najmniej 31\% wszystkich pożyczkodawców, choć ich realny udział w rynku, zapewne znacznie poważniejszy, jest trudny do ustalenia ze względu na niezachowanie ksiag kahalnych. Mimo wzrostu liczby zapisywanych transakcji od lat 70. XVIII w. na białostockim rynku kredytowym nie ma śladów procesów modernizacyjnych, widocznych choćby w Warszawie, a zdecydowana większość transakcji należy do sfery tradycyjnego kredytu prywatnego, którego rozpoznanie powinno być jednym z priorytetów polskiej historiografii gospodarczej. Miasteczka pokroju Białegostoku stanowiły zdecydowaną większość organizmów miejskich Rzeczypospolitej, ale ocena ich poziomu życia gospodarczego wymaga studiów komparatystycznych, których zdecydowanie brakuje. Należy podkreślić, że przedstawiony $\mathrm{w}$ niniejszym artykule obraz wzajemnych pożyczek na procent, oparty na analizie ksiag miejskich, nie uwzględnia roli, jaka w białostockim rynku kredytowym odgrywał garnizon wojskowy oraz dożywotnia posesorka Izabela z Poniatowskich Branicka. Zagadnienia te niewątpliwie wymagają oddzielnego opracowania, będą one przedmiotem moich dalszych badań.

\section{Bibliografa}

\section{Źródła archiwalne}

Archiwum Główne Akt Dawnych w Warszawie: Archiwum Branickich z Białegostoku, sygn. 8, 48; Archiwum Roskie, Akta osobisto-rodzinne i majątkowo-prawne, sygn. 628, 633, 634, 636, 640, 645, 651; Księgi miejskie białostockie, sygn. 1-3.

Archiwum Państwowe w Białymstoku, Teki Glinki, teka 122.

\section{Źródła opublikowane}

Pałac Branickich $w$ Białymstoku, t. 1: Inwentarze $z$ XVII i XVIII stulecia, cz. 1-2, oprac. K. Łopatecki, W. Walczak, Białystok 2012.

Pałac Branickich w Biatymstoku, t. 2: Lata 1802-1809, oprac. K. Łopatecki, W. Walczak, Białystok 2015.

Spisy mieszkańców Białegostoku z lat 1799-1853, oprac. W. Wróbel, Białystok 2016.

Volumina legum, t. 8, Petersburg 1860. 


\section{Opracowania}

Dunin-Wassowicz A., Kapitat mieszczański Nowego Sacza na przełomie XVI/ XVII wieku. Wptyw na ekonomikę miasta i zaplecza, Warszawa 1967.

Kornatowski W., Kryzys bankowy w Polsce w 1793 roku: upadtość Teppera, Szulca, Kabryta, Prota Potockiego, Eyszkiewicza i Heyzlera, Warszawa 1937.

Kusiński W., Przemiany funkcji Białegostoku w przeszłości, „Rocznik Białostocki" 6, 1966, s. 267-296.

Lech M.J., Białystok - miasto i jego mieszkańcy $w$ XVIII w., „Rocznik Białostocki" 6, 1965, s. 441-454.

Lech M.J., Dzieje i obraz Biategostoku w XVIII w., w: Studia i materiaty do dziejów miasta Biategostoku, t. 1, red. J. Antoniewicz, J. Joka, Białystok 1968, s. $129-150$.

Leszczyński A., Żydzi Ziemi Bielskiej od połowy XVII w. do 1795 r. (studium osadnicze, prawne $i$ ekonomiczne), Wrocław 1980.

Łopatecki K., Ustrój XVIII-wiecznego miasta Białystok, „Miscellanea Historico-Iuridica" 14, 2015, z. 1, s. 349-379.

Łopatecki K., Kupczewska M., Dyspozycje majatkowe Izabeli z Poniatowskich Branickiej na wypadek śmierci, KHKM, t. 64, 2016, nr 4, s. 485-493.

Maroszek J., Rzemiosto $w$ miastach podlaskich $w$ XVI-XVIII $w$., w: M. Kwapień, J. Maroszek, A. Wyrobisz, Studia nad produkcja rzemieślnicza $w$ Polsce (XIV-XVIII w.), Wrocław 1976, s. 88-195.

Mączak A., Kredyt w gospodarce chtopskiej na Żutawach Malborskich poczattu XVII w., PH, t. 51, 1960, z. 2, s. 285-313.

Morgensztern J., Operacje kredytowe Żydów w Zamościu w XVII w. (wierzytelności $i$ zadłużenia), „Biuletyn Żydowskiego Instytutu Historycznego” 64, 1967, s. 3-32.

Mościcki H., Białystok - zarys historyczny, Białystok 1933.

Mycio A., Formy kredytu mieszczańskiego na poczattu XVII wieku w świetle ksiag tawniczych Starego Miasta Torunia, „Rocznik Toruński” 26, 1999, s. 55-70.

Oleksicki A., Rozwój przestrzenny i struktura ludności Białegostoku w XVIII wieku, w: Studia nad społeczeństwem i gospodarka Podlasia $w$ XVI-XVIII wieku, red. A. Wyrobisz, Warszawa 1981, s. 31-90.

Oleksicki A., Socjotopografia Biategostoku w XVIII w. w świetle inwentarza miasta $z$ 1771/72 i planu Beckera z 1799 r., w: Studia i materiaty do dziejów miasta Białegostoku, t. 4, red. H. Majecki, Białystok 1985, s. $41-56$.

Rybarski R., Kredyt i lichwa w ekonomii samborskiej w XVIII wieku, Lwów 1936.

Samsonowicz H., Studia nad renta miejska $w$ Prusach $w$ XV wieku, „Zapiski Historyczne" 25, 1960, z. 2, s. 35-57.

Szafran P., Kredyt na Żuławach Gdańskich w XVII-XVIII wieku, „Rocznik Gdański” 45, 1985, z. 1, s. 139-148. 
Sztachelska-Kokoczka A., Handel w miastach dóbr podlaskich Jana Klemensa Branickiego, w: Miasto, region, społeczeństwo. Studia ofiarowane profesorowi Andrzejowi Wyrobiszowi w sześćdziesiata rocznice Jego urodzin, red.

E. Dubas-Urwanowicz, J. Urwanowicz, Białystok 1992, s. 101-110.

Sztachelska-Kokoczka A., Biatystok za pałacowa brama, Białystok 2009. Żabiński Z., Systemy pieniężne na ziemiach polskich, Wrocław 1981.

Monika Kozłowska

The credit market in eighteenth-century Białystok in the light of municipal registers

(Summary)

The article presents the results of an analysis of the credit market in Białystok in the second half of the eighteenth century. The analysis has been based on the oldest municipal registers preserved in Białystok, which were supplemented by documents kept in the Roskie Archives and the Branicki Archives in Białystok. There are 264 entries in the preserved source texts pertaining to loan agreements. The analysis includes such elements of the credit market as: the frequency and values of entries, duration of contracts, and their guarantees.

The credit market of Białystok consisted mainly of small loan agreements (to 100 Polish zlotys), taken out for one year, although a majority of loan agreements did not stipulate a time for repayment. In addition, a large part of loans was secured, most often by pawns of small properties (mainly clothes). The development of credit and monetary transactions was highly influenced by Jews who, according to the information from the source material, made at least 31 per cent of all loaners; their real market position, probably much more influential, is difficult to establish in the face of the lack of kahal registers. Despite the increase in the number of transactions from the 1670s, there are no traces left of any modernisation processes in the Białystok credit market, and a vast majority of transactions belongs to the sphere of traditional private credit - its study should be one of the most important purposes of social historians in Poland.

Monika Kozłowska - historyk, doktorantka w Instytucie Historii i Nauk Politycznych Uniwersytetu w Białymstoku. Zainteresowania badawcze: historia społeczno-gospodarcza. Przygotowuje rozprawę doktorską podejmującą problematykę wpływu zmian klimatu na gospodarkę Rzeczypospolitej przedrozbiorowej, ze szczególnym uwzględnieniem okresu tzw. małej epoki lodowcowej. 
Monika Kozłowska - historian, PhD student of the Institute of History and Political Sciences, University of Bialystok. Her research interests focus on socio-economic history. She works on her doctoral thesis about the influence of climate changes on the economy of the pre-partitioned Polish-Lithuanian Commonwealth, with special emphasis on the so-called Little Ice Age. E-mail: mkozlowska92@o2.pl. 